\title{
A Study of the Cytoplasmic Components and Inclusions of the Developing Guinea Pig Egg*
}

By

\author{
H. W. Beams and R. L. King \\ Department of Zoology, State University of Iowa
}

Ricceived January 27, 1937

Numerous studies have been made upon the relationship of the cytoplasmic components to yolk formation in the developing eggs of many different kinds of invertebrates, however, fewer and less complete studies of this kind have been recorded for the eggs of mammals. The present paper aims to extend these observations for mammals by attempting to follow the normal history of the yolk and fat inclusions from their appearance in the young primordial ova up until the time of ovulation, and to correlate, as far as possible, the observations and terminology of the earlier workers upon these subjects with those of the current literature. In addition, the method of centrifuging, which hitherto has been confined largely to the eggs of invertebrates and those of the frog, has been utilized for the first time to determine the relative specific gravity, and to aid in the identification of, the various materials in the eggs of mammals at different stages in their development.

\section{Material and Methods}

The ovaries of sexually mature non-pregnant guinea pigs were fixed in Champy's, Flemming's, Bouin's and Zenker's solutions, and subsequently stained in Heidenhain's hematoxylin, Delafield's hematoxylin or Mallory's triple stain. Some of the tissue fixed in Champy's solution was impregnated with 2 per cent osmic acid at 36 degrees C. for 5 to 6 days. Sections were cut, bleached and stained in acid neutral red according to the method of Ludford ('25). In successful preparations following such a technique the Golgi apparatus, mitochondria, "yolk nucleus", fat bodies and yolk inclusions are all clearly demonstrated. Therefore, most of our study has been based upon this type of preparation.

\section{Historical}

The "yolk nucleus" seems to have been first observed by von Wittich (1834) in the egg of a spider. Balbiani, in a series of papers

Aided by grant from the Rockefeller Foundation for work on Cellular Biology. 
from 1846 to 1893 , was the first to describe and figure this structure in the eggs of mammals. It has subsequently been studied in various mammals by Henneguy (1893), Martens (1895), Winiwarter (1900) and Hollander (1904). For the more recent contributions on this subject the reader is referred to the paper by Van der Stricht ('23) and by Corner ('32).

Sjövall ('06) is usually given credit for first describing the Golgi apparatus in the eggs of mammals, although it had been figured before, particularly as a negative image by Holmgren ('00). More recently Weigl ('12), Rio Hortega ('13), Kulesch ('14), Cattaneo ('14), Gatenby and Woodger ('20), Henneguy ('26), Nihoul ('26), Bhattacharya ('31), and Gresson ('33) have all described the Golgi apparatus in one form or another in the eggs of various mammals. Gresson ('33), seems to have made the most complete study of this subject in developing eggs of the mouse, and it will be seen that our results upon the guinea pig corroborate his to a great extent.

It is difficult to state who was actually the first to describe the mitochondria in the eggs of mammals, but certainly they were figured as long ago as 1882 by Flemming. Lams and Doorme ('08), Russo ('10), Levi ('15), Monterosso ('15), Kingery ('18), Henneguy ('26), Van der Stricht ('23), Salzar ('31) and Gresson ('33) have all contributed to this subject.

\section{Nomenclature Concerning the "Yolk Nucleus"}

The term "yolk nucleus" has been quite generally used in the older literature to describe a cytoplasmic body, found in many different kinds of developing eggs, which has been linked directly with the origin of yolk by many authors. It can be easily differentiated from the surrounding cytoplasm and is usually located in a juxtanuclear position. It has been described in the literature under many different captions, i.e.: vitelline nucleus, Dotterkern, embryonic vesicle, Balbiani's body, cytocenter, Golgi apparatus, mitochondria, centrosome and sphere, chromidia, cytoplasme germinale and synthetic center.

In this paper, we have decided to retain the term "yolk nucleus" for the juxtanuclear aggregated body found in the young ova of the guinea pig, not because we believe it a completely satisfactory term, but simply for convenience. This term implies that the body is connected directly with the yolk formation but there is a considerable amount of reliable evidence to show that it may have little or nothing to do with the origin of yolk, at least, in many types of eggs. 
The "Yolk nucleus", which is present only as an aggregated body in the primordial guinea pig ova, is heterogeneous in structure (diagram 1A) usually composed of two centrioles (diplosome), surrounded by an osmiophobic or chromophobic plasma which is very probably identical, in so far as structure is concerned, with the idiosome material of early spermatocytes (diagram 1B). Attached to the periphery of the idiosome is the classical osmiophilic Golgi material, the appearance of which seems to vary slightly depend-

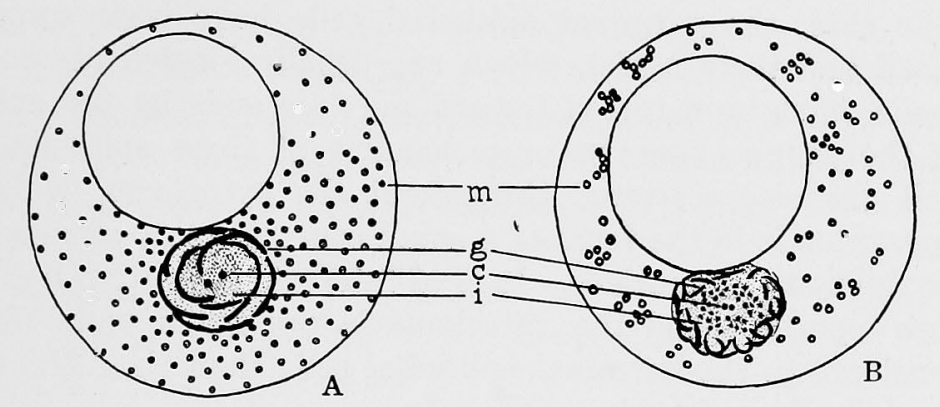

Diagram 1. Diagrams showing the structure and homology of the young guinea pig ovum and spermatocyte. A, Young ovum showing the heterogeneous structure of the "yolk nucleus" and the distribution of the mitochondria. c, centrosomes (diplosome); i, osmiophobic idiosome; g, Golgi apparatus; m, mitochondria. B, spermatocyte, labels as in A (redrawn and slightly modified from Gatenby and Woodger). The proacrosome granules in the idiosome of the spermatocyte are not present in the ovum.

ing upon the degree of impregnation with osmic acid. We have not observed that the mitochondria actually form a part of the "yolk nucleus" in the guinea pig as has been held by some, particularly Van der Stricht ('23). On the other hand, the mitochondria appear in our material as granular bodies scattered more or less evenly throughout the cell, with perhaps only a slight concentration in the region of the "yolk nucleus"

\section{Description}

Normal ova. In the guinea pig ovary it is clear that the young primordial ova may be found within the germinal epithelium, but whether they are actually genetically derived from the cells of the germinal epithelium, or whether they are only temporarily situated there has long been a question of dispute. We do not wish to enter into a discussion of this point here, but merely state that our work confirms, for the most part, that of Evans and Swezy ('31) and of many others who believe that the young germ cells are derived directly 
from the cells of the germinal epithelium. However, in any case, all the stages in development of the ova from the very young (small) ones in the germinal epithelium to the more mature ones in the Graffian follicle and those ready for ovulation may be found in young sexually mature guinea pigs.

In figure 1 is illustrated a primordial ovum situated between the cells of the germinal epithelium. It will be observed that at this stage these young ovarian germ cells are considerably larger and much more rounded than are the cells of the germinal epithelium. In this particular case, the germinal epithelial cells have been somewhat compressed and their nuclei, which are usually located at the base of the cells, have been forced toward the free ends by the enlargement of the young ovum, the mitochondria of these epithelial cells are small granules scattered throughout the cytoplasm, while the Golgi apparatus is in the form of a small compact mass or masses in close proximity to the nucleus. It is of interest to mention here that the Golgi apparatus and the mitochondria are much more difficult to demonstrate in the germinal epithelial cells than they are in the cells more deeply situated in the ovary.

The young ova located in the germinal epithelium show mitochondria which are distributed throughout the cell in the form of small granules and a more or less concentrated type of Golgi apparatus (fig. 1). As the ovum grows and sinks below the basement membrane of the germinal epithelium into the connective tissue stroma of the cortex (tunica albuginea) a well defined "yolk nucleus" in the form a diplosome-idiosome-Golgi apparatus complex makes its appearance in a juxtanuclear position (fig. 2). The mitochondria remain scattered throughout the cytoplasm.

It is difficult to determine just what the morphology of the Golgi material is at this stage, in as much as its appearance varies slightly both with the degree of osmic acid impregnation and also, after staining in Heidenhain's hematoxylin. However, it appears to be in the form of rodlets or a loose network which surrounds and encloses the idiosome. Occasionally one may find an ovum at this stage of development in which the Golgi material has not all collected around the idiosome (fig. 3), a condition comparable to that in the spermatocytes of man as described by Gatenby and Beams ('36).

As the ovum continues to grow, an interesting change is noted in the "yolk nucleus": it begins to break up and disperse in the form of irregular masses, rods and granules (figs. 4, 5, 6). Just what stimulus causes this change in the "yolk nucleus" is by no means clear, however, it appears simultaneously with the growth and enlargement of the cell. We have been unable to follow the history of the diplo- 
somes, that is, to determine whether or not a change in their position might possibly have initiated the dispersal of the "yolk nucleus"

It is equally difficult to determine in osmic acid preparations whether or not the idiosome material still remains associated with the Golgi material after it is broken up. However, in very feebly impregnated ova at this stage and in Champy-hematoxylin preparations one often sees bits of osmiophobic material associated with the classical Golgi material, which definitely indicates that the idiosome material actually breaks up with the Golgi apparatus during the dispersal of the "yolk nucleus" Furthermore, no remains of an idiosome is left to mark the former position of the typical "yolk nucleus"

In still later stages of development, that is, just before the appearance of a follicular cavity, the Golgi material has further dispersed in the form of irregular masses with a slight concentration at the periphery of the cell; the mitochondria are seen still to be distributed fairly evenly throughout the egg (fig. 7). Each of the follicle cells at this stage shows a polarized Golgi apparatus which frequently, but not always, is located on the side of the nucleus facing the egg. Finally in figure 8 is depicted a nearly ripe Graffian follicle showing the egg enclosed in the discus proligerus, the follicular cavity, and the membrana granulosa cells. The dispersed "yolk nuclear" material (Golgi apparatus-idiosome-complex), is observed to be completely broken up into small irregular bodies or frequently into fine granules. The mitochondria have the same general distribution as they did in the younger ova described above. A very striking appearance of the Golgi material and mitochondria of the follicular cells is illustrated here. The Golgi material is generally polarized toward the egg or toward the follicular cavity - a condition which is taken to indicate that the more physiologically active pole of the cell is marked by the position of the Golgi apparatus. Careful study of the zona pellucida following osmic acid impregnation methods reveals a fine and delicate reticulated net or "canal-like system" within it. Whether or not this is an artifact or actually represents a system of nutritive canals for the passage of materials from the follicular cells into the egg we cannot at present say.

Centrifuged ova. In figures $9,10,11,12,13$ and 14 are shown the effects of centrifuging the ovary at 150,000 times gravity for 30 minutes in the ultracentrifuge recently developed by $\mathrm{J}$. W. Beams and A. J. Weed ('31). In all cases, the mitochondria are found to be heavier than the cytoplasm and are displaced to the centrifugal pole of the cells. The "yolk nucleus" in the young ova is usually near the middle or in the centripetal half of the cells (figs. 9, 10 and 11). This condition seems to be the case in about 75 per cent 

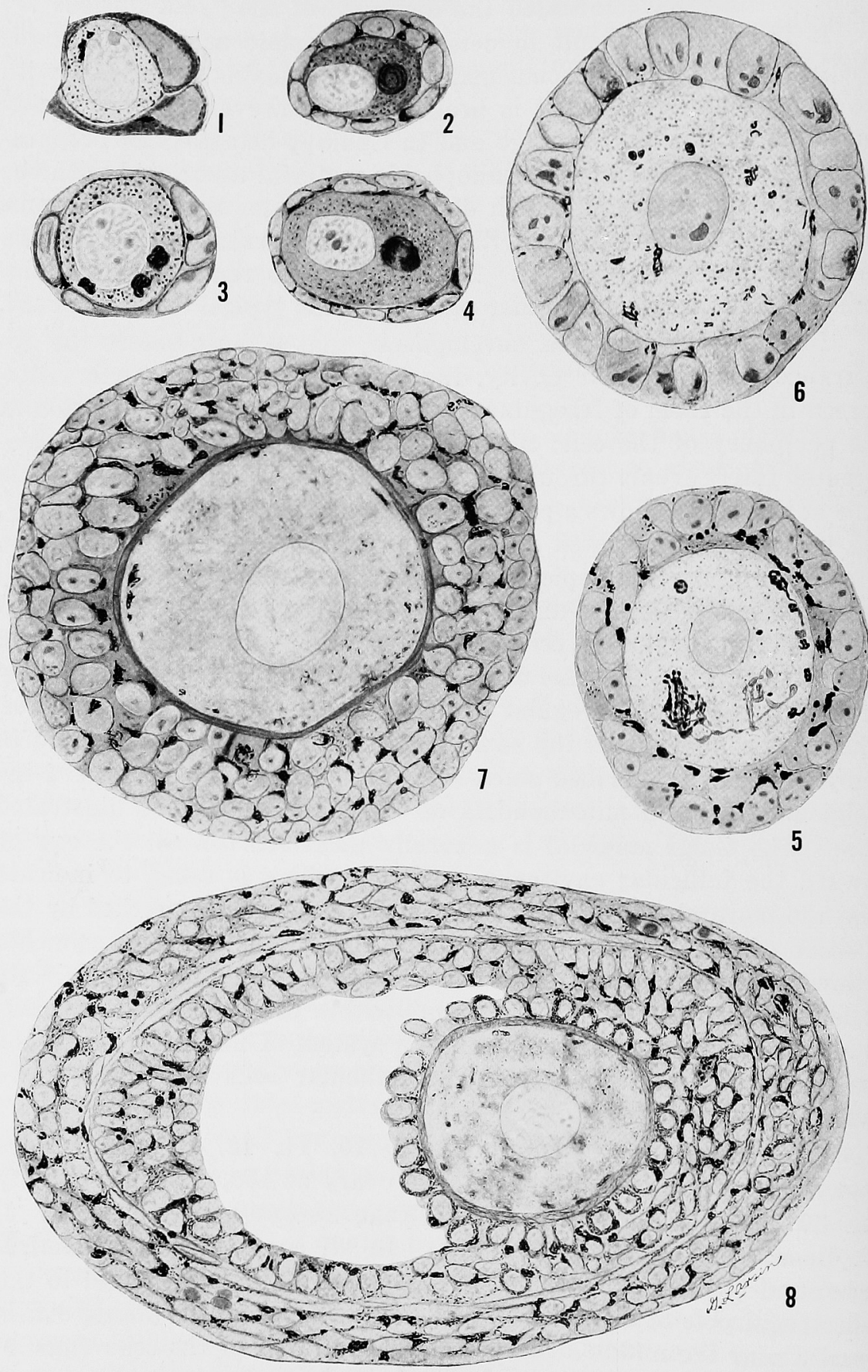
of the young ova. In the remaining 25 per cent the material of the "yolk nucleus" may be displaced among the mitochondria at the centrifugal pole of the cells. Whether or not this variation is due to a difference in specific gravity within the cell or to simple mechanical reasons we are unable to state. The distribution of the cellular elements after centrifuging is directly comparable to that in centrifuged Helix spermatocytes (Beams, Gatenby and Muliyil '36). Furthermore, Nath ('29) working on the eggs of the mosquito seems to have been the first to displace the Golgi apparatus in egg cells.

In the mature ova the typical distribution of the cytoplasmic materials after centrifuging is illustrated in figures 12, 13, and 14 . Fat globules which darken with osmic acid are always collected at the centripetal pole (figs. 13, 14). Yolk granules which are probably represented by brownish colored bodies in the osmic acid preparations are collected centripetal to the mitochondria in the centrifugal half of the egg (figs. 13 and 14). The nucleus may or may not show marked displacement within the cell. Its contents, regardless of the stage in development, are usually stratified, so that the nucleoli and chromatin are at the centrifugal pole and the lighter nuclear sap at the centripetal pole. This is the usual distribution of materials in centrifuged nuclei (Dornfield '36; Beams and King '34).

Atypical ova. A few cases of polynuclear ova have been found (fig. 17). In the literature on this subject, according to Hartmann ('26), three possibilities have been suggested regarding the origin of polynuclear ova, namely, by amitosis, by mitosis of the nucleus only, or by the fusion of two or more egg cells which were originally distinct. Our studies support the view that they may arise by mitosis of the nucleus without division of the cytoplasm in the manner shown in figure 18. The Golgi apparatus and the mitochondria are seen distributed throughout the cell.

In figure 18 is shown a cell in the metaphase stage of division within the follicle, while this condition is not the normal one, or at

Figs. 1-8. All figures are of normal guinea pig eggs and follicles. 1. Young ovum, between two germinal epithelium cells, showing the Golgi material and mitochondria. 2. Young ovum in cortex of ovary; "yolk nucleus" (diplosome-idiosome-Golgi apparatus complex) clearly shown. Mitochondria scattered throughout the cytoplasm. 3. Ovum in which the Golgi material bas not all collected around the "yolk nucleus" 4, 5 and 6. Ova showing progressive stages in the breaking up and dispersal of the "yolk nuclear material", simultaneously with the enlargement of the ova. 7. Later ovum with several layers of follicle cells. Mitochondria scattered through the ooplasm, Golgi apparatus in the form of small masses concentrated at the periphery of the cell. The Golgi apparatus of the follicle cell is usually in a position adjacent to the egg. 8 . Nearly ripe ovum; mitochondria and Golgi material scattered throughout the ooplasm; a fine reticular net work in the zona pellucida. The Golgi apparatus in follicle cells is usually polarized toward the ovum or follicular cavity; mitochondria of the follicular cells are in the form of fine filaments. 

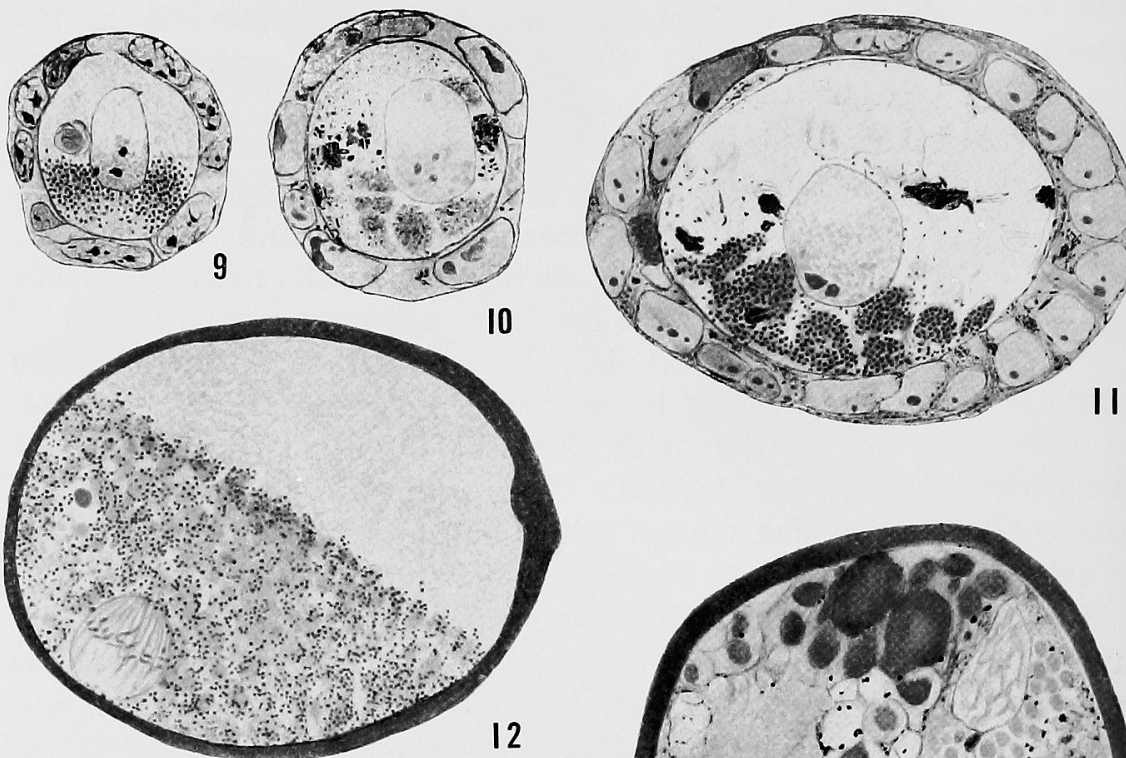

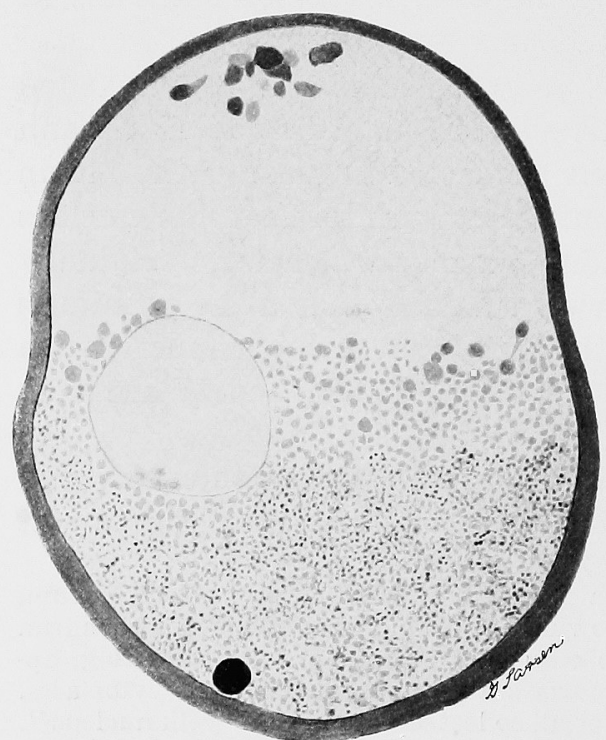

14

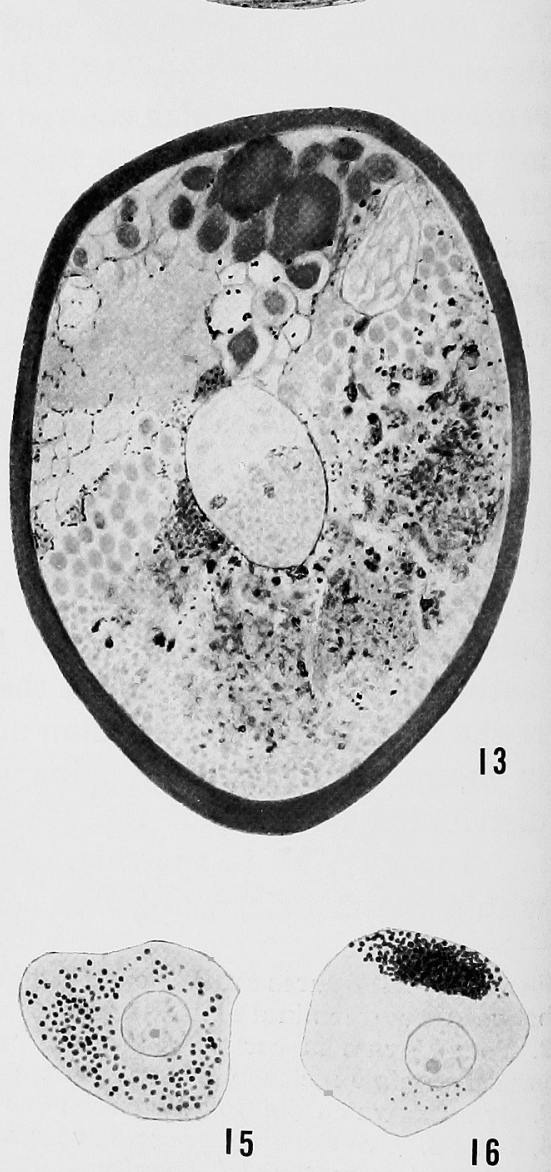

13

16

Figs. 9-16. All figures except 15 are of cells which have been centrifuged 150,000 times gravity for 30 minutes. The direction of the centrifugal force has been toward, or approximately toward the bottom of the plate. 9. Young ovum; the mitochondria are displaced to the centrifugal end of the cell; the "yolk nucleus" (diplosome-idiosome; the Golgi apparatus portion is not shown) is near the middle of the cell. The nucleus shows typical stratification, i. e., the chromatin and nucleoli centrifugally and 
least the usual one for the egg, it nevertheless shows beautifully the distribution of the cellular elements during mitotic division. Here the Golgi apparatus and presumably the idiosome material, although it is not clearly differentiated, is in the form of very fine granules about equally distributed at the two poles of the spindle. This condition of the egg dividing within the follicle and the factors causing it has been adequately discussed by Loeb ('32) and others for the guinea pig.

Frequently polyovular follicles which contain two, three, or as many as 15 ova have been found in the guinea pig (figs. 19, 20, and 21). Each of the young ova show the typical cytological structures as above described for the normal ones. Hartmann ('26) has recently given an excellent review and made a critical study of polyovular follicles in the opossum and states that they have been described as arising by division of polynuclear ova, by concrescence, by previously separated follicles and by persistent union (failure of separation) of ova in Pfluger's egg tubes. We agree with him that the latter view seems the more plausible, at least for the guinea pig.

Centrifuged corpus luteum cells. Osmic acid preparations of the ovaries demonstrate the fat and what appears to be secretion granules so clearly in the corpus luteum cells that it seemed desirable to illustrate them here (fig. 15). After centrifuging, the fat is displaced to the light or centripetal pole and small brownish granules (secretion?) appear at the centrifugal pole of the cell (fig. 16). The relative volume of these materials and other inclusions in these cells might quite accurately be determined by the centrifuge method.

the nuclear sap centripetally. 10 and 11. More mature cells showing the mitochondria at the centrifugal side of the cell. The broken up "yolk nucleus" near the middle of the cell. 12. Egg undergoing first maturation division. It is unknown whether or not the maturation spindle was normally located in this position or was actually displaced by the centrifuging; the mitochondria fill the centrifugal half of the egg. 13. Nearly ripe egg; the mitochondria and what appears to be the dispersed "yolk nuclear material " concentrated in the centrifugal end of the cell; the yolk inclusions are stratified in the middle and the fat globules are collected in to the centripetal end of the cell. 14. Egg just ready for ovulation; mitochondria displaced to centrifugal end of cell; yolk inclusions stratified in the middle, just centripetal to the mitochondria; a layer of clear cytoplasm just centripetal to the yolk inclusions, and globules of fat at the centripetal end of the cell, The Golgi apparatus is not shown in this egg. The nucleus has been slightly displaced to the side and is located just centripetal to the mitochondria. The nucleolus has been forced through the nuclear membrane and is seen as a dark body at the centrifugal end of the cell. 15. Uncentrifuged corpus luteum cell showing fat granules. 16. Centrifuged corpus luteum cell with secretion granules (?) at the centrifugal pole, and the fat bodies displaced to the centripetal pole of the cell. 


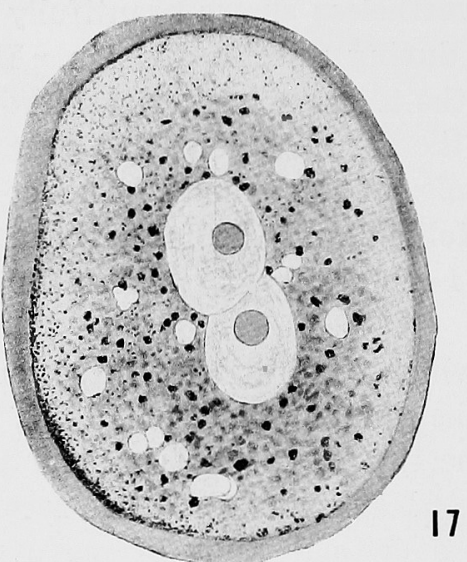

17

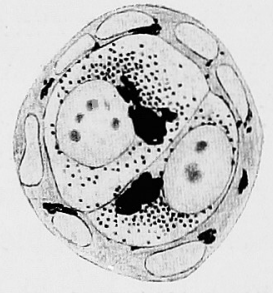

19

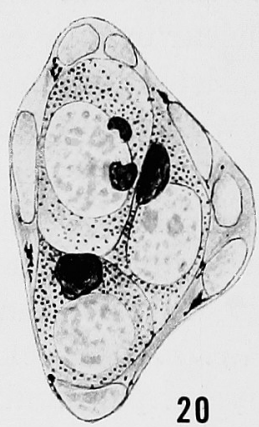

20

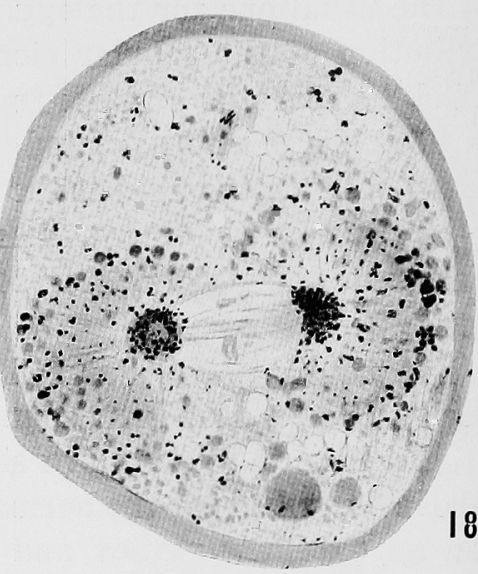

18

21

Figs. 17-21. 17. Polynuclear ovum, showing small granular mitochondria concentrated at the periphery of the cell. The Golgi material is in the form of small scattered masses. 18. Mature egg showing mitotic figure with Golgi apparatus concentrated around the centrosomes. The yolk inclusions also show a certain orientation about the centrosomes and asters. 19-21. Polyovular follicles with 2, 3 and 15 eggs respectively. Mitochondria and Golgi apparatus appear as in the egg of the normal follicle.

\section{Discussion}

As previously pointed out, the subject of the structure, origin and function of the so called "yolk nucleus" has been one of long standing and current conflicting opinion. It has been thought to represent a pathological formation in the egg, extrusion of nuclear material, engulfed wandering ameboid cells, or a body which directly gives rise to yolk. More recently Bounoure ('30, '32) in a series of papers has developed the interesting hypothesis that it represents a "cytoplasme germinale"; a sort of "keimbahnplasma" or germ cell determinant. The well known papers of Gatenby and his students, of Nath and his students (see MacBride and Hewer '31 for references to these works), and by others have shown that in many cases, par- 
ticularly in invertebrate eggs, the "yolk nucleus" or, more specifically, the material of which it is largely composed, the Golgi apparatus, is directly linked with the origin of yolk. Gresson ('33), although unable to find direct evidence, nevertheless concludes that the Golgi apparatus and mitochondria play some part in the formation of yolk in the egg of the mouse. In a recent extensive and commendable paper, Payne ('32) has critically studied the cytoplasmic components and inclusions in the developing ova of several different species of insects and was unable to find evidence that either the mitochondria or Golgi apparatus directly give rise to yolk. He thinks of the "yolk nucleus" as a synthetic center, a center of great activity, where yolk, fat, vacuoles, and other chemical substances are synthesized, and questions whether its early position near the nucleus has any particular significance.

The guinea pig egg, while not suitable material for the study of yolk formation, nevertheless affords no evidence that the mitochondria or the Golgi apparatus play a direct part in the synthesis of yolk beyond that as integral parts of the cell system as a whole. However, we wish to make it clear that we do not deny that the Golgi apparatus or mitochondria may function directly in yolk formation in other types of eggs.

As regards the function of the mitochondria, Harvey ('36) has recently presented some very interesting observations. She has found that cell fragments completely void of mitochondria may divide and develop beyond the many cell stage in certain sea urchin eggs. In other words, her work demonstrates that mitochondria are not essential for the life of the cell. We have in progress similar experiments upon Ascaris eggs which seem to support her conclusions; however, we do not wish to make a definite statement upon this important point at this time.

We look upon the "yolk nucleus" complex in the young guinea pig egg as similar in structure to the idiosome-Golgi apparatus complex in spermatocytes as deseribed by Gatenby and Woodger for the guinea pig, and Gatenby and Beams for man, with, of course, the exception that there are no proacrosome granules present. In addition, two distinct parts of the idiosome portion of the "yolk nucleus" of the egg can be demonstrated and they appear to be directly comparable to the idioectosome and idioendosome of the primary spermatocyte of the guinea pig as figured by Papanicolaou and Stockard ('18). We are not convinced that the idiosome-Golgi apparatus complex of spermatocytes or of the "yolk nucleus" in the guinea pig ova are necessarily specific for germ cells. Careful study of large leucocytes (unpublished data) reveals also a structure, comparable to these 
elements in the germ cells. It possesses diplosomes, embedded in an idiosome material, which is in turn surrounded by the Golgi apparatus. If this interpretation be correct, we cannot accept the hypothesis of Bounoure that these materials are specific for germ cells or that they are germ cell determinants, at least for the guinea pig. Moreover, Hirschler and Gatenby have definitely traced the genetic continuity of these components from the egg to the various cells of the body, both somatic and germ. Furthermore, if the germ cells are derived from the germinal epithelial cells, as there is good evidence for believing, then the Bounoure theory cannot be right.

Recently Brambell ('26) has described the infiltration of Golgi material into the egg of the fowl from the follicular epithelium. Battacharya, Das and Dutta ('29) found the same condition for the tortoise and P. R. Bhattacharya ('31) reports a similar phenomenon for the squirrel, rabbit and rat.

In the guinea pig we have found no evidence that the Golgi material passes from the follicle cells into the egg. Furthermore, we have found the Golgi material in the follicle cells to be in the form of a compact mass or network polarized at the side of the nuclei as described by Gresson and others and not in the form of small granules as depicted by Bhattacharya ('31). That there may be small canals or striations in the zona pellucida, as described by the older workers (see for instance Retzius '12), is suggested by examination of osmic acid preparations. We have found instances that resemble closely those figured by Russo ('10) showing the apparent migration of the mitochondria through the zona pellucida, but as to the significance of these preparations we are not, at present, prepared to say.

O. Van der Stricht ('23) has summarized his numerous works upon the "yolk nucleus" of various mammals in an extensive paper. Our work differs from his mainly in that, what he apparently calls pseudochromosomes we believe to represent the Golgi apparatus. Furthermore, we have not found such a clear concentration of the mitochondria into a so-called mitochondrial layer surrounding the "yolk nucleus" as has been figured by him. Our work is more in line with Gresson's on this point and we have found only one type of mitochondria present.

\section{Conclusions}

1. A study of the cytoplasmic components in the developing guinea pig egg has been made by the usual cytological methods. In addition the method of centrifuging has proven a valuable aid in determining the relative specific gravity and identity of the different materials within the egg. 
2. The "yolk nucleus" of the young ovum is a heterogeneous structure, composed of centrosomes (diplosome) embedded in an osmiophobic idiosome which is in turn surrounded by the Golgi material.

3. As the young ovum grows and enlarges the "yolk nucleus complex" breaks up and becomes dispersed throughout the cytoplasm.

4. The mitochondria in all stages of the developing ovum are in the form of granules which are distributed for the most part throughout the cytoplasm of the cell. No direct relationship of the mitochondria with the "yolk nucleus" was observed.

5. The cytoplasmic components of the ova after centrifuging are stratified from the centrifugal to the centripetal pole as follows: 1. a layer of mitochondria; 2. nucleus; 3 . "yolk nucleus material" in about 75 per cent of the cases, in the remaining 25 per cent it is found among the mitochondria; 4. yolk granules, when present; 5. a layer of clear cytoplasm; 6. a layer of fat inclusions, when present in the cell.

6. The Golgi apparatus in the follicle cells is usually, but not always located on the side of the nucleus directed toward the egg or follicular cavity. Numerous filamentous mitochondria occur scattered throughout the cytoplasm of the follicle cells.

7. A delicate network or canal-like system is frequently seen in the zona pellucida after impregnation with osmic acid. The exact nature or significance of this structure is not, at present, clear.

8. Several cases of polynuclear ova in guinea pig ovaries have been found. A few ova with typical mitotic figures showing the distribution of the mitochondria and Golgi material during division have been observed.

9. Polyovular follicles with as many as fifteen ova, showing typical cytoplasmic components, have been figured.

10. Cytoplasmic inclusions of the corpus luteum cells can be easily displaced by the centrifuge.

\section{References}

Allen, E. 1923. Ovogenesis during sexual maturity. Am. Jour. Anat., vol. 3.

Balbiani, E. G. 1893. Centrosome et "Dotterkern". Jour. Anat. et Physiol., T. 29.

Beams, H. W. and R. L. King 1934. The effects of ultracentrifuging upon the Golgi apparatus in the uterine gland cells. Anat. Rec., vol. 59.

Beams, H. W., Gatenby, J. B. and J. A. Muliyil 1936. Ultracentrifuging the spermatocytes of Helix aspera. Quar. Jour. Micr. Sci., vol. 78.

Beams, J. W. and A. J. Weed 1931. A simple ultracentrifuge. Science, vol. 74.

Bhattacharya, P. R. 1981. The infiltration of Golgi bodies from follicular epithelium to the egg in mammals. Allahabad University Studies, vol. 7 .

Bhattacharya, D. R., Das, R. S. and S. K. Dutta 1929. On the infiltration of the Golgi bodies from the follicular epithelium to the egg. Zeit. f. Zellf. u. Mikr. Anat., Bd. 8. 
Bounoure, L. 1930. Sur l'existence et la localisation dans les premiers blastomères de la grenouille d'un matérial cytoplasmique distinct destine au germen, C. R, Soc. Biol., T. 108.

Bounoure, L. 1932. L'immortalité est elle un attribut de la vie ? Rev. Gen. des Sci., No. 15.

Bowen, R. H. 1922. On the idiosome, Golgi apparatus, and acrosome in the male germ cells. Anat. Rec., vol. 24.

Brambell, F. W. R. 1925. Oögenesis of the foul (Gallus bankiva). Phil. Trans. Roy. Soc., vol. 214.

Cattaneo, D. 1914. Ricerche sulla struttura dell 'ovario dei mammiferi. Arch. Ital. Anat. Embr., vol. 12.

Corner, G. W. 1932. Cytology of the ovum, ovary and fallopian tube. Chapter 39 , vol. 3, Special Cytology, Edited by E. V. Cowdry, New York.

Dornfeld, E. J. 1936. Nuclear and cytoplasmic phenomena in the centrifuged adrenal gland of the albino rat. Anat. Rec., vol. 65.

Evans, H. M. and Olive Swezy 1931. Ovogenesis and the normal follicular cycle in adult mammalia. Memoirs of the Univ. of Cal., vol. 9.

Flemming, W. 1882. Zellsubstanz, Kern und Zelltheilung. Leipzig.

Gatenby, J, B. and J. H. Woodger, 1920. On the relationship between the formation of yolk and the mitochondria and Golgi apparatus during oögenesis. Jour. Roy. Micro. Soc. 1920.

Gatenby, J. B. and J. H. Woodger 1921. The cytoplasmic inclusions of the germ cells. Part 9 . On the origin of the Golgi apparatus on the middle-piece of the ripe sperm of cava, and the development of the acrosome. Quart. Jour. Micr. Sci. vol. 65. (References to Prof. Gatenby's earlier papers on spermatogenesis will be found here).

Gatenby, J. B. and H.W. Beams 1936. The cytoplasmic inclusions in the spermatogenesis of man. Quar. Jour. Micr. Sci., vol. 78.

Gresson, R. A. R. 1933. A study of the cytoplasmic inclusions and nucleolar phenomena during the oögenesis of the mouse Quart. Jour. Micr. Sci., vol. 75.

Hartman, C. G. 1926. Polynuclear ova and polyovular follicles in the opossum and other mammals, with special reference to the problem of fecundity. Am. Jour. Anat., vol. 37.

Harvey, E. B. 1936. Parthenogenetic merogony or cleavage without nuclei in Arbacia punctulata. Biol. Bull., vol. 71.

Henneguy, M. G. 1893. Le corps vitellin de Balbiani dans l'oeuf des vertébrés. Jour. Anat. de Physiol., T. 29.

Henneguy, L. F. 1926. Sur la situation de l'appareil de Golgi dans les cellules folliculaires de l'ovarire de Cobaye. C. R. Soc. de Biol., T. 94.

Hollander, F. 1904. Recherche sur l'oogenese et sur la structure et la signification du noyau vitellin de Balbiani chez les oiseaux. Arch. d'anat. microsc., T. 7.

Holmgren, E. 1900. Von den Ovocyten der Katze. Anat. Anz., Bd. 18.

Kingery, H. W. 1918. Oögenesis in the white mouse. Jour. Morph., vol. 30.

Kulesch. L. 1914. Der Netzapparat von Golgi in den Zellen des Eierstockes. Arch. f. mikr. Anat., Bd. 84 .

Lams, H., and J. Doorme 1908. Nouvelles recherches sur la maturation et la feccndation de l'oeuf des mammifères. Arch. de Biol., T. 23.

Levi, G. 1915. Ll comportameto die condriosomi durante i piu precoci periodi dello sviluppo dei Mammiferi. Arch. f. Zellforsch., Bd. 13.

Loeb, Leo 1932. The parthenogenetic development of eggs in the ovary of the guinea pig. Anat. Rec., vol. 51.

MacBride, E. W. and H. R. Hewer 1931. Recent advances in microscopy. Section III. Edited by A. Piney, London.

Mertens, H. 1895. Recherches sur la signification du corps vitellin de Balbiani dans l'ovule des mammifères de des oiseaux. Arch. de Biol., vol, 13.

Monterosso, B. 1915. Su l'origine e la constituzione dei materiali deutoplasmici nell occite in accrescimento dei Mammiferi. Arch. f. Zellforsch., Bd. 13.

Munson, J. P. 1912. A comparative study of the structure and origin of the yolk nucleus. Arch. f. Zellforseh., Bd. 12. 
Nath, V. 1929. Studies on the shape of the Golgi apparatus. Zeit. f. Zellforsch. u. mickr. Anat., Bd. 8.

Nihoul, J. 1926. Recherches sur l'appareil endocellulaire de Golgi dans les premièrs stades du développement des mammifères. La Cellule, T. 37.

Papanicolaou, G. N. and C. R. Stockard 1918. The development of the idiosorre in the germ-cells of the male guinea-pig. Am. Jour. Anat., vol. 24.

Payne, F. 1932. A study of the cytoplasm in insect ova. Jour. Morph., vol. 53.

Retzius, G. 1912. Biologische Untersuchungen. Bd. 17.

Rio Hortega, P. 1913. Détails nouveaux sur la structure de l'ovaire. Trab. Lab. Invest. Biol., T. 11.

Russo, A. 1910. Sui mutamenti che subiscono i mitochondri ed i materiali deutoplasmici dell oocite di coniglia in diversi periodi di inanizione. Arch. f. Zellforsch., vol. 10 .

Salazar, A. L. 1931. Quelques points de l'histologie de l'ovaire de la Lapine. Travaux de l'Inst. d'Hist. et d'Embr. Universite de Porto, Vol. 2.

Sjövall, E. 1906. Ein Versuch des Binnennetz von Golgi-Kopsch bei der Spermato- und Ovogenese zu homologisieren. Anat. Anz., Bd. 28.

Skrobansky, L. 1903. Zur Frage über den sogenannte Dotterkern (corpus Balbiani) bei Wirbeltieren. Arch. f. mikr. anat., Bd. 63.

Van Bambeke, 1898. Contributions a l'histoire de la constitution de l'oeuf. Arch. de Biol., T. 15.

Van der Stricht, O. 1923. Etude comparée des ovules des mammifères aux différentes périodes do l'ovogenèse, d'après les travaux du Laboratoire d'Histologie et d'Embryologie de l'Université de Gand. Arch. de Biol. T. 33.

de Winiwarter, H. 1900. Recherches sur l'oogenèse et l'organogenèse de l'ovaire des mammifères (Lapine et Homme). Arch. de Biol., T. 17.

Von Wittich 1845. Observationes quaedam de Aranearum ex ovo evolutione. Halis. (Quoted from Munson '12).

Wilson, E. B. 1925. The cell in development and heredity. New York. 